\title{
The Rationale for Subsidy of Higher Education in Hong Kong: A Sensible Decision from An Economic Viewpoint
}

\author{
Chan Shing Yin Amy \\ Teaching Fellow I \\ Department of Curriculum and Instruction \\ Hong Kong Institute of Education \\ 10 Lo Ping Road, Tai Po, New Territories, Hong Kong \\ Tel: (852)-2948-8103Ｅ-mail: shingyin@ied.edu.hk
}

\begin{abstract}
This paper is an attempt to draw the statistical data from reports and documents to reveal the rationale for subsidizing the higher education in Hong Kong. There is a discussion made with reference to educational planning interacting with personal choice. The notion of economics has been noted with consideration of allocation of scarce resources and how the behaviour is adjusted by means of the mechanism and the optimization of goal. The higher education institutes can assist the improvement of the local regime through the training of competent and responsible professionals. Financing higher education is sensible as the optimization of goal is obvious.
\end{abstract}

Keywords: Higher Education, Hong Kong, State Subsidy

\section{Introduction}

The rationale for state subsidy of higher education has stimulated discussion among various parties. Economists would often use an input-output model to make analysis. Politicians would like to cater for the interests of the voters. Individual would like to satisfy the individual needs. To cater for different parties' interests, we have to make sensible decision. Sensible decision is generally regarded as good decision-making and right decision-making which may lead to proper action. We usually determine whether it is a sensible decision from an economic viewpoint. Economics is concerned with the production, distribution and consumption of goods and services. And certainly, the cost-benefit would be the answer.

Before we go deep into the discussion, there is a need to define the terms for discussion. The term "subsidy" refers to the "funding" of the higher education institute and releasing the grant and loan to the students studying in the higher education institutes. The funded programmes refer to the undergraduate programmes in this article, unless otherwise specified. Besides, the knowledge and competence developed through initial schooling and formal higher education for young people would be our focus of discussion.

The underlying principle for state subsidy of higher education would be the perception of investment in human capital. Besides, the financing of higher education is also guided by the principles of equity. It would allow the low-income group students who are capable to carry on their study in higher education without financial burden. Whether it is sensible from an economic viewpoint depends very much on its benefits, in other words, the cost-benefit.

This paper attempts to present the information drawn from the documents and reports. The role of the Hong Kong government will be presented prior to the major discussion. There will be two major parts in this article. The first part is an outline of the justification for the state subsidy of higher education and a sketch for the possible reasons for the intervention in higher education. The arguments in the investment of human capital will be made clear. The second part is a review on the decision and the rationale will be justified by the cost-benefits. The statistical figures from various reports will be supporting arguments. The social benefits gained from higher education will be clarified. Alternatives of the subsidized higher education and that is, the privatization of higher education services will also be discussed.

\section{The setting: the role of Hong Kong government}

There is no doubt that the primary function of the government is to maintain social security and public order. In addition, the task of the government is to maintain and enforce the normal way of behaving. It implies that the government has to enhance the community well-being and development. It is the routine of the government to manage the resources well and allocate the resources fairly. The role of the government is perceived as the provider in the sector of basic education. As a provider, the government has to provide the services. However, the 
higher education services is offered by the academic institutes which is responsible for research and teaching. The role as a funder and the regulator of educational services for the government in the higher education is more appealing. As a funder, the government has to offer different level of mechanisms. The local higher education institutes have received different kinds of grants for the daily operation and the students are also entitled to apply for grants and loans as provided by the government. As a regulator, the government's role is to regulate the provision of services.

\subsection{The role as a provider}

It is assumed that the government is responsible for the provision of goods and services to the public. Education is generally accepted as a public good and human right. There is no doubt that the government should subsidize education. As mentioned, the provision of elementary and secondary education services is obvious because the system is under control. It would assume standardisation to a certain extent. And the access to the compulsory and free education has to be made to all by law. Furthermore, the national values can be delivered through the subsidized education.

The government has aimed at providing "opportunities for everyone who aspires to higher education to attend programs appropriate to their abilities" and "to establish a diversity of institutions" for meeting learners' choice (Education Commission: 1999, 18). But the provision of the subsidized higher education is perceived as a personal investment. It seems that the subsidy is not economical. And even if the government is agreeing on providing the services, should the government provide the higher educational services directly or should the government play a monitoring role instead, allowing academic autonomy in the higher education? In other words, there should be job specialization. Since the academic institutes specializes in the pursuit of knowledge, it is more appropriate for the institutes to take up the role. The local government should subsidize the higher education and place less control.

\subsection{The role as a funder}

Currently, the government is funding the eight higher education institutes and providing the higher education services indirectly using the taxpayer's money. The role as a funder is apparent.

Funding the local higher education institutes is to enhance the political intervention or academic development for the good of the society which upholds some basic principles. The principles of inclusiveness and access foster an equal opportunity in the public education system. Such a commitment creates the circumstances in which there are a large variety of shared undertakings and experiences. The Hong Kong government serves as a funder and the funding provides financial assistance to individuals who, for some reasons, are unable to participate fully.

There are two level mechanisms of state subsidy of higher education by the Hong Kong government, namely the institutional level mechanisms and individual level mechanisms. The institutional level mechanisms in Hong Kong refer to the Recurrent grant and Non-recurrent grant. The former one is the grant allocated to institutions as a block grant across teaching, research and widening participation in line with the way the grant is announced. The latter one is a summary of the grant expenditure on special funding programmes and earmarked capital.

Another commonly found practice is called the student grant and loan scheme. It is regarded as the individual level mechanism. The students are in need of financial assistance can either borrow the money or get the grant from the government. Chung (1996) has reported on the latest development. The Student Financial Assistance Agency (SFAA) which was established in 1990 administered a great variety of student finance assistance schemes covering the needs of students from pre-school to higher education, including the Local Student Finance Scheme (LSFS). The LSFS subsumed all major financial assistance to higher education students. Those eligible local students are entitled to receive the grant up to the full amount of the tuition fees and the loan up to $\$ 36880$ for 2009/2010.

\subsection{The role as a regulator}

University Grants Committee(UGC) (Note 1) "firmly believes that Hong Kong must have its own strong higher education system as its future depends upon harnessing knowledge and understanding to define the cultural vision, and create and respond to economic opportunity". In order to fulfill this role, the UGC as a statutory body, ensures that "at system level, appropriate tools, mechanisms and incentives are in places to assist institutions to perform at an internationally competitive level in their respective roles". By the term "incentives", it unquestionably refers to the grants the institutions receive. Contemporary education policy stresses "accountability" and the regulation takes many forms. Here, in Hong Kong, and the government is relying on the UGC to function the task well. It asserts the quality assurance, the pedagogy and the academic production of the funded higher education institutes. 
The UGC has conducted various peer reviews as a quality assurance initiative. Such an action would enhance the funded higher education institutes to meet the requirements of the government. These requirements include the pedagogical practices and academic production achievement.

The local context has been made clear to the reader and that we can proceed to the discussion of the dominant role taken by the government in funding and regulating the higher education in Hong Kong.

\section{Possible reasons for government intervention in education}

The government has to undertake a lot of considerations in higher education policies and such an action would possibly lead to the strategies in the intervention in higher education. It is not merely judging from an economic viewpoint though education is seen as a national investment. Sometimes or more often, it is a political one. The Economics of Education is responsive to the needs of the national economy. It would be financed by the State and, theoretically, at least, be open to all citizens. The government's active role in the financing and regulating higher education services implies that many of the issues are resolved through political mechanisms interacting with the individual decisions. As stated in the above session, the principles of inclusiveness and access have to be considered. And the pursuit of equity is the crucial factor that justifies the intervention.

\subsection{Equity and opportunity}

In contemporary societies, educating the young is the responsibility of the public. One of the government's principal aims is to secure increased participation of individuals from the lower socio-economic groups in higher education. We suppose the education system is fair to all and the screening device of the educational system would be able to identify the abilities of those capable students, regardless of their family background. If it is believed that those who are intellectually capable should be encouraged to carry on their further study, the subsidy has to be made available. What the public is most concerned is the income-related equity. Higher education is expensive and never be free. The average student unit cost of UGC-funded Programmes in 2007/08 for the undergraduate program is $\$ 240000$ (Note 2) for a three year study. If the users have to pay all the costs or the tuition fees, it would exert a huge burden to the low-income group families. The latest monthly household statistics shows that the median monthly household income for the poorest district is $\$ 13,800$ (Note 3 ). The lowest-income group families would, therefore, find difficulties in supporting one or more than one members to study in the higher education institute and pay for the expenses if there is no subsidy. And the young generation may have to be forced to enter the labour market with inadequate skill training or qualification. In that sense, the higher education needs to be financially aided and opportunities can then be provided to the vulnerable. The young generation of the low-income group families can subsequently be offered the opportunities to get to the higher education. Moreover, this is the way to minimize the intergenerational poverty by helping the youth to be well-equipped so as to enhance their employability and self-confidence before their entry to the labour market. Eventually, social mobility can be allowed. To conclude, the principal of equal opportunities should be respected and the financing of higher education must be entirely public.

\subsection{Investment in Human capital and social investment}

Schultz (1971) and Becker(1993) are seminal references on education as investment in human capital. The purpose of education is twofold according to them. They are building human capital by teaching skills that directly improve productivity. Woodhall (1987) has defined the term human capital as "human beings invest in themselves, by means of education, training, or other activities, which raises their future income by increasing their lifetime earnings." Undoubtedly, the human capital is the skills and knowledge acquired by an individual and developed primarily by education and training. Education develops skills of work and enables the worker to be productive. In other words, the narrow sense of the human capital model would value knowledge and skills instrumentally as they contribute to increased productivity and other things being equal, higher earnings.

It is true to the government which would view it technically. The Hong Kong government views the human capital as an important asset. During the past few years, the former Chief Executive Tung Chee Hwa has emphasized the importance of human capital with the context of knowledge-based economy in the policy address(Note 4). It is an investment according to the local government's viewpoint. Indeed, human capital competencies are perceived as a key component of value in a knowledge-based economy. Absolutely, knowledge is seen as a kind of commodity and high-skilled labours are required in the knowledge economy. The education of the people is crucial to our prosperity. In this respect, the government has to analyze the market thoroughly and be responsible for making a forecast in manpower requirement so as to plan well for the supply of labour. 
On the other hand, the government and the people share the same beliefs that people's lives can be improved with the increased income, the crime rate would usually decrease. There is no doubt that the society would become more stable.

\section{Sensible decision from Economic viewpoints or not}

Brewer and others (2008:25; cited in Ladd) has denoted the term "Economics" and "the activities of the Economists". Economics is often defined as "the study of the allocation of scarce means to satisfy competing ends" (Walberg 2003 cited in Brewer 2008:25). The activities of the economists are listed as follows:

"Economists study how individuals, organizations, and societies employ time, money and effort. In the case of education, economists are interested in how society organizes and uses resources to produce various types of knowledge and skills through formal schooling and distributes them to various groups in society”.

He (2005:25-26)further claimed that the economic theories are built on three basic foundations, namely, scarcity, rationality, and optimization.

In Hong Kong, normally eighteen percent(Note 5) of the secondary school leavers can enter the first year of the funded undergraduate programmes. It is understood that the resources are constrained and the taxpayers and the economists are concerned with the distribution of resources. The principles that underpin and sustain funded higher education are those principles related to, firstly, the inclusion of all students, secondly, the provision of opportunities, thirdly, the searching for quality in education and fourthly, the beliefs towards the contribution to economic growth. It is true that if not all, then most of the secondary school leavers would prefer carrying on their study in the higher education institutes. As the funded university places are limited, it is difficult to satisfy people's unlimited wants. The intervention seems necessary to alter the people's behaviour. That's the very basic idea of the supply and demand mechanism where funded higher education places can be allocated through a recognized system. At the same time, the scarce resources can be distributed rationally and the goal of the secondary school leavers can be optimized.

\subsection{Is providing opportunities to all a sensible decision?}

The first principle of the government's intervention is to provide opportunities to all. There are two arguments that we have to consider whether funding the higher education institutes is sensible.

First, some may argue that the pursuit of higher education study is a personal investment and higher education is not purely a public good. The median salary as indicated by the survey is above $\$ 10,000$ (Note 6) for the university graduates and the private rate of return is relatively high. One can guarantee a high income after the completion of study. It should be viewed as a consumer good in line with this argument. If higher education is an investment good by the consumers and the profit of higher education is very high, the costs should be wholly or partly supported by the students. An alternative would be the handover of the provision of the higher education to the private education sector. The provision of private higher education services may ease the financial burden of the government. The consumers, the students would make careful decision before they enroll the courses. It would definitely avoid the wastage in the expenditure on higher education by the government. Along with this argument, there is no justification that the government should subsidize the study. However, relying the private sector may induce certain threats to the quality of the education. The poorer sections of the population may be under-served, which in turn will leave the workforce under-skilled though private higher education can be a good option for the secondary school leavers. Furthermore, there is no promise that the private higher education sector could assure quality since the private higher education institutes would normally operate on a profit gaining mode. The survey done by Morgan and others (2008) would make the illustration clear. The study has reviewed the current situation for the development of private higher education in China. The likely trend in several key areas, which includes the governmental regulation and competition for enrolments, has been discussed. The article also brings out specifically on how it affects the quality of the private higher education and the acquisition of labour market qualifications by low-income students in China. For the situation in Hong Kong, there is not much research done on the operation of the privately-run higher education institutes because the local privately-run higher education institutes have a comparatively short history. It is difficult to make a comparison at this moment. But we believe that the survey results have an implication on the situation in Hong Kong. And the case would be similar.

And second, there is an assumption that the provision of funded higher education places is the fundamental responsibility of the government. This is not what we want to see if there is extreme social stratification in the liberal society, with the rich becomes richer and the poor becomes poorer. Notably, the cost is difficult to calculate. Possibly, it can be an investment without rates of return at the beginning. But it is understood that the 
cost of cultivating a harmonious society would be great. These are the expenses that we have to pay. Or we may need to pay higher opportunity cost for the social security or correctional services if we disregard the importance of social cohesion.

To sum up, the provision of the funded higher education places would be meaningful on the condition that the quality is high in a liberal society.

\subsection{Labour forecast}

It is the government's duty to make a forecast on the labour supply. It is necessary to make intervention in a sense that any miscalculation in the labour supply would result in wastage. The following is an example.

A lot of secondary school students are lacking of the information for the future labour market. They are making decision according to their own interests, life experiences or exposure. For instance, a survey which was led by Lai (2009) (Note7). has shown that potential pre-service teachers are more interested in becoming secondary school teachers, instead of primary school teachers. There is a salary gap between primary and secondary school teachers. The students prefer teaching in the secondary schools because they believe that there would be better conditions come up with employment in secondary schools. Another factor which is not shown in the study may be concerned with the status. Usually, the secondary school teachers receive more respect than the primary school teachers. But in the coming few years, there is an urgent need of the primary school teachers in Hong Kong. By intervention, it may mean that the government would allow more funded Full Time Equivalents (FTE) in the training of the primary school teachers and reduce the funded FTEs for the training up of secondary school teachers. The government is very likely to provide more specific training to cater for the employers. If the government does not make any intervention but to satisfy all those secondary school leavers to focus on the study teaching in secondary schools, it may leave to the unbalanced supply of teachers. On the one hand, the local primary school sectors are in great need of trained teachers and they are unable to recruit the trained graduates. On the other hand, the trained undergraduate students who focus on their study in secondary school subjects discipline may find difficulties to be employed after the completion of study. To avoid the mismatches, we can presume that any intervention in the supply of the subsidized places in the universities would undoubtedly change the demand or the behaviour. The government's intervention might be useful in adjusting the supply and demand mechanism. Such a mechanism would help stabilize the situation. The government responds to the needs of the society and allocates the scarce resources to the appropriate parties. And the primary school sector would be satisfied by the sufficient supply of the trained teachers. It is sensible from an economic viewpoint as the government is planning for a balanced supply of the trained labour for the local educational sector and to prevent any unemployment. The funding is therefore regarded as sensible because the government is forecasting the labour supply. Such a planning is stemmed from an economic point of view.

\subsection{Quality assurance}

As suggested, the possible reason for the government to intervene the provision of higher education by means of funding is that education is perceived by a lot of people as a public good. However, according to the economists, the free market generates the biggest prosperity. It would lead to the efficient distribution and in this case, the allocation of resources. The criticism towards subsidy by the government on the higher education would be the criticism of efficiency. Given that the higher education institutes do not compete with each other, it is very likely that they do not have any intrinsic to offer a better choice. This is exactly what happened before the mid nineties in Hong Kong. It was criticized by the educationalists (Cheng 1995 and Ho 1998). Cheng and Ho's criticisms focused on the academic output. But it is also generally perceived as the lack of competition. The funded higher institutions can choose not to answer the preferences of the students or the public or offer the new "products". They can choose to provide a uniform education choice. Again, by these two theories, criticisms towards efficient and benefit, there is no ground that the government should subsidize the higher education. However, as stated in the previous paragraphs, the role of the government is a regulator and the government is responsible to monitor the quality of the higher education institutes. Indeed, the Hong Kong government is playing the regulating role by means of institute level funding and the delivery of courses is monitored by the UGC. In the first place, the higher education institutes have shown significant improvements in the publication areas (Note 8). The publication of academic journal has risen tremendously for some particular subject discipline in some universities. And secondly, the UGC has made some suggestions on the direction of the various funded universities. These suggestions are corresponding to the vision and mission as outlined in the webpage. For instance, the deep collaboration among the universities would be an example. The HKIEd was requested to run joint programmes with the Lingnan University or Chinese University and currently the HKIEd is operating such courses(Note 9). And in fact, the index(Note 10) has shown that the funded universities, instead of the privately 
run, are the most popular. The UGC has made a lot of suggestions in the direction of the various funded universities.

The funding is sensible in the sense that it has achieved the targets of the government and the quality has been assured.

\subsection{Optimization of goal}

Third foundation of economics is profit gaining or optimization of goal. As pointed out earlier, it can be profit or goal maximization. The question that we are going to suggest would be what benefits could be gained from higher education.

\subsubsection{What Does Individual and Society Gain from Higher Education?}

Bloom, D. E. and Sevilla, J. (2003) has explained the concept of "social benefits".

"Social benefits include the private benefits enjoyed directly by the individual, such as higher earnings through life. But they also include public benefits, that is, benefits that society derives from higher education over and above those enjoyed by the individual himself or herself."

They further illustrated four types of human capital that we are in need in the contemporary society. They are people who can exercise liberal citizenship, entrepreneurship and demonstrates the capacity of the globalized and knowledged workers. Under the knowledge economy, these four types of human capital are important and have been expressed in the local educational reform document (ED 2000). The government is happy to see these four types of human capital to be developed after training or education.

Indeed, Dearden and others (2005) have summed up some benefits that the society may benefit. It is listed as follows:

- the well educated tend to be more flexible and innovative in response to the unexpected, better able to cope with problems in family and community, less dependent upon services supplied by the state, and inspired with that "passionate inquisitiveness to continue learning through life" (Council for Industry and Higher Education) that lies at the heart of so much educational and socio-cultural endeavour.

- a worthwhile higher education can help to reduce the excessive and unrealistic expectations that constitute one of the downsides of technological and scientific advance and of consumer capitalism, and thus counter the socially and politically disruptive consequences of such expectations remaining unfulfilled.

In that sense, the individual benefits from higher education would usually be regarded as the monetary return. The public benefits from higher education would be a growing economy and the competitiveness in the world by means of human capital. The individual and public benefits would be regarded as a kind of profit.

\subsubsection{The profitability of investment in education}

If we regard education as a kind of investment, then the term "profit" would be the money reward for individual or economic growth by the government. Usually, the non-monetary reward is excluded. Economists typically view education or training as an individual investment decision designed to achieve a monetary return in the labour market and have also highlighted the strong correlations between educational levels and a number of other private and public social benefits. Individuals who have invested in education and job-training often have more job stability. The statements are supported by various research findings. Mincer (1958) has asserted the fact that "Differences in training result in differences in level of earnings among occupations as well as in differences in slopes of lifepaths of earnings among occupations. The differences are systematic; the higher the occupational rank, the higher the level of earnings and the steeper the life-path of earnings". Psacharopoulos (1973, 1981; cited in Quiggin 1999) has also made a similar note. Incomes increase with the level of education and that the implied private and social rates of return to education are high. McIntosh (2008) has undertaken a survey that the unemployed rate for university graduates is much lower. Though the survey was done in the countries other than in Hong Kong, the result is convincing. The Hong Kong By-census report (2007) Table 3.17 (Note 11) has clearly specified that the higher the educational level attainment, the higher the income. The research findings have indicated very clearly the individual rates of return. With higher income, people are usually more contented and very much likely, they can afford to spend more on daily living. The expenses would in turn contribute to the economic growth.

To my understanding, the term "profit" can be viewed more broadly. The human capital theory may be interpreted more largely, to encompass learning that does not contribute to higher market earnings. The pursuit of the knowledge or capacity may provide a happy life pattern but not to be reflected in market earnings. Or we regard a sense of satisfaction in life or to achieve a goal in the life. And the society is then more stable. Another 
example would be the well educated mothers who are not involved in economic productions but solely devote themselves to the upbringing of the children. It seems to be a loss in both ways, the earnings of the non-working mothers and the social investment throughout the years in training or other expenses. Yet the society can benefit from another way. The full time well educated mothers would undeniably raise a better generation. And it can't be calculated straightly in money terms.

Hence, in a wider spectrum, the term "profit" may also refer to the third basic foundation of the economic theories, optimization of goals, be it happiness or others. For instance, according to the local Chinese newspaper reporting (Note 12), after the JUPAS reprioritisation process, the competition for the Philosophy programme offered by the Lingnan University became the keenest, with 36 students competing for 1 place. Interestingly, this program has no relation with the key industries in Hong Kong and it seems that, the students taking this program are not urging for the monetary return but what they perceive the most valuable could be cognitive learning. To them, the profit gained can be the knowledge itself or the happiness that is generated in the process.

It is noted that the university leaders seldom emphasize the broader social benefits of offering post-secondary study opportunities to a larger proportion of the population in public. But it is generally convincing that better educated people make a more active and effective contribution to the development of the voluntary sector. Clearly as indicated as above, one of the key benefits of the society is the contribution of a highly qualified workforce to the Hong Kong's international competitiveness. Second, it is believed that the investment made by the government can turn the society to be or tend to be a peaceful one and reduce the risk of intergenerational poverty. As put forward in the above, the improvement in the income of the under-skilled would result in the job security or possibly the decrease in crime rate. And that the government may spend less in the social security, especially for the Comprehensive Social Security Assistance or presumably in the other areas. It would certainly echo the first point that I have made in the previous session. With the deduction in the cost in the other areas, it could be counted as a gain for the government.

\subsubsection{The contribution of education to economic growth}

Inevitably, the contribution of education to economic growth is an economic consideration for funding of higher education. It is believed that education does contribute to economic growth, however the truth is we cannot prove it easily. There is currently no survey done on the rates of return for local situation systematically to the best of my knowledge. But if we trace the research done before, we can depict one. Wong \& Chung (1992:17-37) have conducted a survey and proved that education has positive correlation with the economic growth which accounted for the period from the mid seventies to eighties. And it is reasonable to assume that there are positive correlations now.

The second point that I would like to raise is about the role that Hong Kong plays in the globalized world. Hong Kong is a free port and an international financial centre. It maintains and develops relations with foreign states and regions, and international organisations in the appropriate fields. The key industries as identified by the Hong Kong government are 1) Financial services, 2)Tourism, 3)Trading and Logistics and 4) Professional Services and Other Producer Services. These are the key industries in globalized economy and knowledge economy. As it is strongly believed that the training in higher education would enhance the skills for future working environment, education would certainly contribute to the economic growth in the way that it can produce the skilled labour to fit the economy.

It is generally accepted that increased investment in higher education would lead to internationally competitive. Likewise, Hong Kong has remained its competitiveness. Hong Kong was ranked as 11 in the Global Competitiveness Index Rankings (Note 13). According to a survey done (C\&SD 2008), Hong Kong was host to 6,612 overseas and Mainland of China companies representing parent companies located outside Hong Kong. Hong Kong continues to be the top choice of location for overseas and Mainland of China companies to manage their regional business. It has yielded a demand for the global workers in Hong Kong in supporting these kinds of companies.

It is sensible that the government would view the funding as the social investment and yield the product that it needs, the economic growth.

\subsection{Cost Benefit}

The term "cost benefit" implies that it is calculating the cost spent and the rates of return. This is an input-output model that is familiar to the economists.

In Hong Kong, the funding of higher education does not take up a significant proportion of GNP and the cost is lower when compared with the developed countries. The Hong Kong government has allocated approximately 
HK\$16 billion (Note 14) through the University Grants Committee in the year 2007-2008. As compared with HK's GNP, the amount is very small. In the first quarter of 2008, Hong Kong's GNP is \$427.3 billion at current market prices and the funding cost is less than 3\%. It is difficult to calculate the direct contribution of higher education to the economic growth. Along with this argument, we can assume that the government is operating well and efficiently with very mean input or low cost. Judging from the small proportion, we can admit that the public is getting the most from the investment in higher education.

The calculation of rates of return is extremely a complex one, especially to those with no or little background in economics. Psacharopoulos (1987: 342) has conveyed the ideas of rates of return. He has distinguished the concept of private and social rates of return. As for the private rate of return, there is no need to elaborate. It was explained under the various sessions above. What I need to clarify is the social rate of return. The social rate of return is used for educational planning. To the economists, the social rate of return reflects the total value of all benefits associated with an investment that accrue to members of society.

In calculating the social rate of return, Psacharopoulos (1987: 343-344) has suggested some information to be considered, like the labour force participation, unemployment and wastage. However the truth is the estimates of the costs and benefits are hard to come by. There is not much literature reviewing the social rate of return. Up till now, I can only locate one piece of systematic analysis on the rates of return in higher education investment in Hong Kong. The research done by Voon (2001) is the one measuring the social returns to higher education investments in Hong Kong using the census and by-census data. The research report has segregated the Hong Kong labour force into two groups: graduate and non-graduate workers. In short, graduate labour comprises all the degree holders and non-graduate labour includes workers with qualifications below the bachelor level. The share of graduate workers (represented as $\gamma$ ) in Hong Kong has increased from 0.038 to 0.210 while that of non-graduate workers (represented as 1- $\gamma$ ) has decreased from 0.962 to 0.790 over the 1976-1996 period. The workforce quality index has significantly increased. The graduate workers with higher wages are deemed to be more productive than non-graduate workers in Hong Kong. It is clear that the funding of the higher education has more positive impacts on labour force and that it is sensible from an economic viewpoint, especially if we focus on the cost-benefit model.

\subsection{A Sensible decision}

The great work of Abraham Maslow has suggested the model of human being's basic needs. And if self-actualization is the ultimate goal of human beings, then the major responsibility of the government is to encourage the citizen to actualize oneself. By doing so, the government has to operate in a balanced financial situation within a stabilized context and that is, to avoid any deficit and to allow the profit. At the same time, the social order is secured. But of course, the basic question we might ask would be how much profit the government is aiming at if the other conditions remain constant. And what is the priority? If the priority goes to education services, should the higher education share the resources? How the government allocate the resources would certainly reflect the governance of the government. The Budget and policy address in Hong Kong has set out very clear picture of the basic values and direction of the Hong Kong government. The basic values of Hong Kong as led by the senior government officials would be helping the disadvantaged and establishing closer link with China, our mother country. The knowledge economy would be the context that we are living.

Given that the knowledge economy is emerging and to cope with such kind of economy would be the first priority of the government. The government has to make investment by developing human capital, no matter at a time when there is economic downturn or rise. The best way of developing human capital would be through education and training. The primary and secondary education would be a long term investment. But the higher education would be a short term investment, responding to the society's immediate needs.

As analyzed above, the basic argument would be, on the whole, there are net social benefits to investments in higher education. The benefits are larger than the costs. Financing the higher education needs careful planning and thorough investigation of needs. By planning, the government has to make accurate forecast on labour force. The supply of funded university school places would then be adjusted. Hence, the secondary school leavers may alter their behaviour by demand and supply mechanism and reacting to the realities. Overall speaking, it is a sensible and careful economic consideration for individual and the government.

It is very natural that the government would minimize the cost by every mean and optimize the goal or the output. It is a cautious way of spending taxpayers' money on the basis of the income. By outsourcing the services would allow certain kinds of flexibilities and increase the productivity. In such a way, the government is performing the role well to plan the economy. Such an economy would differ from the free market operation as the government's intervention is necessary. These are very basic and sensible economic considerations. Sometimes, 
the cost for maintaining a stable society would be very huge. But it is unavoidable as it is the underlying belief of the government to be inclusive. The maintenance of orderly society is a must for all societies.

Illustrations of the sensible decision from economic points of view by different perspectives have been expressed above. To reiterate my points, it can be seen that it is sensible from an economic point of view if there is a subsidy to the higher education. All the figures have shown evidence on the gains from the investment, regardless of a personal or social investment. As knowledge is a kind of new commodity in the new economy, there is a pressing need to equip the young with the generic skills to adapt to the environment.

\section{Conclusion}

In this paper, the context focuses on the undergraduate programmes that the majority of secondary school leavers are aspiring in Hong Kong. There is an attempt to justify the rationale for funding the local higher education institutes in Hong Kong. But we pay particular attention to the economic viewpoints with reference to the educational planning interacting with personal choice. The notion of economics has been noted with consideration of allocation of scarce resources and how the behaviour is adjusted by means of the mechanism and the optimization of goal. The social investment with respect to the government's interests or social interests has played a part to the financial subsidy to the higher education institutes. The training offered by the higher education institutes would probably contribute to the economic growth in Hong Kong. The government has to assure the quality as well and it is sensible to subsidy the higher education.

The statistics undertaken by the Hong Kong government has revealed the fact that there is private benefit to the individual. Yet the government has to fund the higher education institutions to enable the output. Hong Kong is regarded as a democratic society and offers equal opportunities to the vulnerable. The government has to take care of all citizens and upholds the principle of equity and allows the access to the higher education by all.

The argument has boiled down to the fact that higher education institutes have a critical role in supporting the knowledge-driven economic. The higher education institutes can assist the improvement of the local regime through the training of competent and responsible professionals. Besides, there is a strengthening purpose and the society can secure public order. Such an idea has been thoroughly discussed in this essay. Financing higher education is sensible as the optimization of goal is obvious.

\section{References}

Anderson, R. E. \& Meyerson, J. W. (1990). Financing higher education in a global economy. sponsored by the National Center for Postsecondary Governance and Finance. New York: American Council on Education.

Becker, G. (1993). Human capital: a theoretical and empirical analysis, with special reference to education. Chicago : The University of Chicago Press.

Belfield, C. R. (2000). Economic Principles for Education: Theory and evidence, Edward Elgar, Cheltenham, England.

Blaug, M. (1992). The Economic value of education: studies in the economics of education. England; Brookfield.

Bloom, D. E. and Sevilla, J. (2003). Public Subsidies for Higher Education in Developing Countries International Higher Education Boston College Center for International Higher Education

Bowen, H. R. (1980). The costs of higher education: how much do colleges and universities spend per student and how much should they spend? San Francisco : Jossey-Bass Publishers.

Bowen, H. R. (1996). Investment in learning: the individual and social value of American higher education. New Brunswick, N.J.: Transaction Publishers.

Census and Statistics Department. (2007). The 2006 By-Census Report.

Census and Statistics Department. (2008). Population and Household Statistics Analysed by District Council District.

Census and Statistics Department. (2008). Report on Annual Survey of Companies in Hong Kong Representing Parent Companies Located outside Hong Kong.

Chung, Y. P. \& Wong, Y. J. et. al. (1992). The Economics and Financing of Hong Kong Education. Hong Kong: The Chinese University Press, 1992.

Dearden, L. E. Fitzsimons, A. Goodman, G. Kaplan. (2005). Higher Education Funding Policy: Who Wins and Who Loses? A Comprehensive Guide to the Current Debate. London: Institute for Fiscal Studies.

Education Commission. (1999). A Holistic Review of the Hong Kong School Curriculum Proposed Reforms. 
Education Department. (2000). Learning to Learn (Consultation Document).

Gradstein, M. (2005). The political economy of education: implications for growth and inequality. MIT.

Ladd, H. F. and Fiske, E. B. (2008) Handbook of research in education finance and policy. New York: Routledge.

Lai, K. C. (2009). Teaching as a Career in Hong Kong: Understanding Secondary Seven Students' Perceptions. Retrieved $27^{\text {th }}$ July, 2009 from http://www.ied.edu.hk/news/eng/press_details.php?id=20090628.

Lee, W.O. (2002). Equity and Access to Education: Themes, Tensions, and Policies. Hong Kong: Comparative Education Research Centre.

McGrath, S. (2004). Globalisation, Enterprise and Knowledge : Education, Training and Development in Africa. Oxford : Symposium Books.

McIntosh, S. (2008). Education and employment in OECD countries. Paris: UNESCO: International Institute for Educational Planning. Also available from the website http://unesdoc.unesco.org/images/0015/001597/159779e.pdf.

Mincer, J. (1958). Investment in Human Capital and Personal Income Distribution. Journal of Political Economy, 66, 281-302.

Morgan, J. \& Li, F. L. (2008). Private higher education in China: access to quality higher education and the acquisition of labour market qualifications by low-income students. Education, Knowledge and Economy. 2 (1), 27-37.

Psacharopoulos, G. (1987). et. al. Economics of education : research and studies. Oxford : Pergamon Press.

Quiggin, J. (1999). Human capital theory and education policy in Australia. Australian Economic Review 32(2), $130-44$.

Schultz, T. W. (1971). Investment in human capital: the role of education and of research. New York: Free Press Social Rates of return (n.d.) Retrieved from http://faculty.ccbcmd.edu/ ryentzer/srr.htm on 27th July, 2009.

UGC. (2004). Hong Kong Higher Education- Integration Matters.

UGC. (2010). Average Student Unit Cost of UGC-funded Programmes by Level of Study, 2002/03 to 2008/09. Retrieved $1^{\text {st }}$ Aug., 2010 http://cdcf.ugc.edu.hk/cdcf/searchStatisticReport.doc.

Voon, J. P. (2001). Measuring social returns to higher education investments in Hong Kong: production function approach. Economics of Education Review. 20(5), 503-510.

\section{Notes}

Note 1. The webpage of the UGC has outlined the mission, policies and activities of UGC. The webpage is listed for reference. http://www.ugc.edu.hk/eng/ugc/index.htm

Note 2. UGC (2010). Average Student Unit Cost of UGC-funded Programmes by Level of Study, 2002/03 to 2008/09.

Note 3. HK Govt (2008). Population and Household Statistics Analysed by District Council District P.12. Retrieved 13th July, 2009 from http://www.censtatd.gov.hk/freedownload.jsp?file=publication/stat_report/social_data/B11303012008AN08B010 0.pdf\&title $=\% a b \% f 6 \%$ b0 $\%$ cf $\% c 4 \%$ b3 $\%$ b $7 \% 7 c \% a 4 \% c 0 \%$ b0 $\%$ cf $\%$ b9 $\%$ ba $\% a 4 \% c 0 \% a a \% b a \% a 4 H \% a 4 f \% a 4 \% c e$ \%a6\%ed\%a4\%e1\%b2\%ce\%adp\%b8\%ea\%ae\%c6\&issue=2008\%a6\%7e\%aa\%a9\&lang=2\&c=1

Note 4. See the policy address in 1997(Paragraph 92-97), 1998(Paragraph 88-90), 1999(Paragraph 74-78), 2000(Paragraph66-68), 2001(Paragraph 33-36) and 2004(Paragraph 43-46).

Note 5 . This is the target of the government, aiming at providing $18 \%$ funded university places.

Note 6. This is taken from the survey results released by local funded higher education institutes by March, May or June every year.

Note7. Lai, K. C. (2009) Teaching as a Career in Hong Kong: Understanding Secondary Seven Students' Perceptions. Retrieved 27th July, 2009 from http://www.ied.edu.hk/news/eng/press_details.php?id=20090628

Note 8. The UGC statistics have shown that in some universities, e.g., the academic publication of the members in the Faculty of Education in HKU rose from 40\% to 80\% approximately during the period 2003-2006.

Note 9. See the report UGC (2004) Hong Kong Higher Education- Integration Matters. It can also be 
downloaded

from

the

website

http://www.ugc.edu.hk/eng/doc/ugc/publication/report/report_integration_matters_e.pdf

Note 10. The Education18.com has conducted the survey on the ranking of Higher Education Institutes and it was widely reported by the local newspaper dated 28th July, 2009. HKU and the other funded universities or higher education institutes have ranked the top 8 places but Shue Yan, the private university has ranked the last place.

Note 11. http://www.statistics.gov.hk/publication/stat_report/population/B11200462006XXXXB0501.pdf

Note 12. Sing Tao, Ming Pao, HK Economic Times, Ta Kung, Sing Pao and Wen Wei made a similar reporting on 7-7-2009.

Note 13. http://www.weforum.org/pdf/GCR08/GCR08.pdf

Note 14. The calculation is based on the average unit cost of the UGC funded programme students multiplies by the total number of the Full Time Equivalent. 